INDONESIAN HEALTH ISSUE

\title{
Pengaruh Aromaterapi Kulit Jeruk Terhadap Intensitas Mual Muntah Pada Ibu Hamil Marlina L.Simbolon ${ }^{1}$, Dormauli ${ }^{2}$ \\ 1-2STIKes mitra Husada Medan \\ Email korespondensi: simbolon.marlina@yahoo.com No HP: 081361922096
}

\begin{tabular}{l}
\hline ARTICLE INFO \\
Received \\
01 Januari 2022 \\
Accepted \\
14 Februari 2022 \\
Published \\
19 Februari 2022 \\
\hline
\end{tabular}

Kata Kunci: Aroma Terapi; Mual muntah; Ibu Hamil

\section{Keywords:}

Aromatherapy;

Nausea;

Pregnant

\begin{abstract}
ABSTRAK
Latar Belakang: Patogenesis Emesis Gravidarum sampai saat ini belum diketahui secara pasti, namun paritas memiliki peran sekitar $60-80 \%$ pada ibu primigravida dan $40 \%$ pada multigravida, usia ibu yang muda, dan kekurangan berat badan serta peningkatan konsentrasi hCG, progesterone dan estrogen, serta peningkatan kadar serum GDF15 dalam darah ibu. Mual dan muntah yang terus-menerus dapat mengganggu dan membuat ketidakseimbangan elektrolit dan cairan pada jaringan ginjal sehingga hati menjadi nekrosis. Metode: Quasi experiment dengan pre test and post test, 32 orang ibu postpartum,tehnik pengambilan data random sampling waktu penelitian Januari - Maret 2021 dan analisi data dengan paired sample $t$ test. Hasil: Adanya pengaruh aroma terapi kulit jeruk terhadap intensitas mual dan muntah yoga postnatal denganP value $(0.000)<\alpha(0,05)$. Kesimpulan: Terdapat pengaruh aroma terapi kulit jeruk terhadap intensitas mual dan muntah.

\section{ABSTRACT}

Background: The pathogenesis of Emesis Gravidarum is not yet known with certainty, but parity has a role of around $60-80 \%$ in primigravida mothers and $40 \%$ in multigravida, young maternal age, and underweight as well as increased concentrations of hCG, progesterone and estrogen, as well as increased levels of serum GDF15 in maternal blood. Nausea and vomiting that continue to interfere and create an electrolyte and fluid imbalance in the kidney tissue so that the liver becomes necrotic.

Purpose: to find out the effect of postnatal yoga on the psychological condition of postpartum mothers. Methods: Quasi experiment with pre test and post test, 32 postpartum mothers, random sampling data collection technique during the research period January - March 2021 and data analysis with paired sample t test.

Conclusion: There is an effect of orange peel aromatherapy on the intensity of nausea and vomiting
\end{abstract}




\section{PENDAHULUAN}

Jumlah kejadian hyperemesis gravidarum mencapai $12,5 \%$ dari jumlah seluruh kehamilan di dunia. Wanita hamil umumnya akan mengalami mual dan muntah selama beberapa bulan pertama kehamilan, walaupun ada juga beberapa wanita yang tidak mengalami rasa mual selama kehamilan pertama tetapi mengalami mual dan muntah pada kehamilan berikutnya. Mual (nausea) dan muntah (emesis) terjadi pada $50-70 \%$ wanita hamil dalam 16 minggu pertama. Kurang lebih $66 \%$ wanita hamil trimester pertama mengalami mual dan muntah dan $60-80 \%$ terjadi pada primigravida serta $40-60 \%$ pada multigravida namun sekitar $12 \%$ wanita hamil masih mengalaminya hingga 9 bulan. (WHO)

Mual muntah pada kehamilan memiliki dampak yang signifikan bagi tubuh dimana ibu menjadi sangat lemah, muka pucat dan frekuensi buang air kecil menurun drastis sehingga cairan tubuh semakin berkurang dan darah menjadi kental (hemokonsentrasi). Keadaan ini dapat memperlambat peredaran darah sehingga suplay oksigen dan makanan ke jaringan juga ikut berkurang hal ini dapat menimbulkan kerusakan jaringan yang membahayakan kesehatan ibu dan janin (Rofiah, 2019)

Yoga postnatal karena berdasarkan pengalaman pribadi, yoga dapat membantu menurunkan tingkat stress dan emosi. Kamei dkk dalam penelitannya menjelaskan bahwa setelah yoga, diketahui serum kortisol dalam darah akan menurun dan mengubah gelombang otak menjadi gelombang alpha (a). Gelombang alpha merupakan gelombang di otak yang berada pada frekuensi 8-13 Hz. Biasanya gelombang ini muncul pada saat manusia beristirahat dengan memejamkan mata, diawal menjelang tidur (Winarni, 2020)

Hiperemesis gravidarum dapat ditangani dengan cara nonfarmakologis salah satunya dengan pemberian aromaterapi. Aromaterapi merupakan metode terapi yang bersifat noninstruktif, noninvasif, murah, sederhana, efektif dan tanpa efek samping yang merugikan. Aromaterapi yang aman digunakan pada saat kehamilan antara lain jahe, anggur dan jeruk (jeruk nipis, jeruk manis dan lemon). Zat yang terkandung dalam kulit jeruk adalah minyak atsiri yang berguna untuk menstabilkan sistem saraf sehingga menimbulkan efek tenang bagi siapapun yang menghirupnya. Selain pengobatan secara nonfarmakologis yang tidak memiliki efek samping dan serta tidak merugikan kondisi ibu dan janin, perawat juga harus memberikan asuhan keperawatan yang tepat kepada pasien hiperemesis gravidarum.

Karena masih banyaknya ibu hamil yang mengalami mual muntah maka dari itu kami tertarik untuk melakukan penelitian tersebut yang bertujuan untuk mengetahui Pengaruh Aromatherapi kulit jeruk terhadap intensitas mual muntah pada ibu hamil di Puskesmas Sei Semayang.

\section{METODE PENELITIAN}

Penelitian ini menggunakan metode quasi eksperimen one group pre test-post test design, di Puskesmas Sei Semayang dan pelaksanaanya Januari - Maret 2021dengan sampel 32 orang. Tehnik pengambilan sampel dengn ramdom sampling, kuesioner pengukuran Edinburg Postnatal Depression Scale (EPDS), analisis data paired sample t test, dan penyajian data univariat dan bivariat. 


\section{HASIL PENELITIAN}

\section{a. Analisis Univariat}

Analisis univariat dalam penelitian in memberikan gambaran karakteristik ibu hamil yang datang ke Puskesmas Sei Semayang Kecamatan Sunggal Kabupaten Deli Serdang yang berjumlah 32 responden meliputi umur, pendidikan, pekerjaan, paritas, trisemester, usia kehamilan. Gambaran karakteristik tersebut dapat dilihat pada Tabel 4.1 dibawah ini

Tabel 1 : Karakteristik Ibu Hamil di Puskesmas Sei Semayang Kecamatan Sunggal Kabupaten Deli Serdang

\begin{tabular}{llcc}
\hline No & \multicolumn{1}{c}{ Karakteristik } & N & \% \\
\hline 1 & Umur & & \\
& $<$ 20 tahun & 2 & 6,3 \\
& 20-35 tahun & 26 & 81,2 \\
& $>35$ tahun & 4 & 12,5 \\
\hline 2 & Pendidikan & & \\
& SD & 2 & 6,3 \\
& SLTP & 9 & 28,1 \\
& SLTA/SMK & 17 & 53,1 \\
& Diploma/Sarjana & 4 & 12,5 \\
\hline 3 & Pekerjaan & & \\
& Tidak bekerja/IRT & 10 & 31,3 \\
& Wiraswasta/Pedagang & 14 & 43,7 \\
& Pegawai Swasta & 6 & 18,7 \\
& PNS & 2 & 6,3 \\
\hline 4 & Paritas & & \\
& Anak ke-1 & 8 & 25 \\
& Anak ke-2 & 14 & 43,7 \\
& Anak ke-3 & 8 & 25 \\
Anak ke- $\geq 4$ & 2 & 6,3 \\
\hline 4. & Usia Kehamilan & & \\
1-4 minggu & 4 & 12,5 \\
& 5-8 minggu & 16 & 50 \\
9-12 minggu & 12 & 37,5 \\
\hline
\end{tabular}

Penelitian ini menemukan Umur ibu hamil yang terbanyak adalah umur 20-35 tahun 26 responden $(81,2 \%)$, pendidikan SMA 17 responden $(53,1 \%)$, pekerjaan sebagai wiraswasta 14 Responden (43,7\%), Paritas 2 sebanyak 14 responden (43,7\%), dan usia kehamilan 5-8 sebanyak 16 responden $(50 \%)$

Tabel 4.2 Frekuansi Mual Muntah sebelum Intervensi pada Ibu Hamil di Puskesmas Sei Semayang Kecamatan Sunggal Kabupaten Deli Serdang Tahun 2021

\begin{tabular}{|c|c|c|c|}
\hline No & Karakteristik & $\mathbf{N}$ & $\%$ \\
\hline \multirow[t]{4}{*}{1} & Mual & & \\
\hline & Ringan & 7 & 21,9 \\
\hline & Sedang & 16 & 50 \\
\hline & Berat & 9 & 28,1 \\
\hline \multirow[t]{2}{*}{2} & Muntah & & \\
\hline & Ringan & 8 & 25 \\
\hline
\end{tabular}




\begin{tabular}{lcc}
\hline Sedang & 16 & 50 \\
Berat & 8 & 25 \\
\hline
\end{tabular}

Berdasarkan Tabel 4.2 dapat dilihat bahwa ibu hamil sebelum intervensi aroma terapi mengalami mual muntah sedang sebanyak 16 responden (50\%) dan yang mengalami mual ringan 7 responden $(21,9 \%)$ dan yang mengalami muntah sama banyaknya ringan dan berat sebanyak 8 responden (25\%).

Tabel 4.3 Frekuansi Mual Muntah sesudah Intervensi pada Ibu Hamil di Puskesmas Sei Semayang Kecamatan Sunggal Kabupaten Deli Serdang Tahun 2021

\begin{tabular}{llccc}
\hline No & & Karakteristik & N & \% \\
\hline 1 & Mual & & \\
& Ringan & 28 & 87,5 \\
& Sedang & 3 & 9,4 \\
& Berat & 1 & 3,1 \\
\hline 2 & Muntah & & \\
& Ringan & 29 & 90,7 \\
& Sedang & 2 & 6,2 \\
& Berat & 1 & 3,1 \\
\hline
\end{tabular}

Berdasarkan Tabel 4.3 dapat dilihat bahwa frekuensi mual dan muntah ibu hamil setelah diberikan intervensi aroma terapi kulit jeruk lebih banyak adalah kategori ringan.

Tabel 4.4 Pengaruh Aromaterapi Kulit Jeruk Terhadap Intensitas Mual Muntah Pada Ibu Hamil Di Puskesmas Sei Semayang Kecamatan Sunggal Kabupaten Deli Serdang Tahun 2021

\begin{tabular}{|l|c|c|c|c|}
\hline \multirow{2}{*}{ Variabel } & \multicolumn{2}{|c|}{ Frekuensi } & \multirow{2}{*}{ df } & p \\
\cline { 2 - 3 } & Sebelum & Sesudah & & \\
Mual & 7 & 28 & 31 & 0,000 \\
Ringan & 16 & 3 & & \\
Sedang & 9 & 1 & & 0,000 \\
Berat & 8 & 30 & 31 & \\
Muntah & 16 & 2 & & \\
Singan & 8 & 1 & & \\
Bedang & & & & \\
\hline
\end{tabular}

Dari Tabel diatas dapat dilihat bahwa terjadi penurunan frekuensi mual dan muntah setelah diberikan aroma terapi kulit jeruk. Hal ini dapat dilihat bahawa ada pengaruh aroma terapi kulit jeruk terhadap intensitas mual dan muntah $p<0,05$ ) 


\section{PEMBAHASAN}

\section{Pengaruh Aromaterapi Kulit Jeruk Terhadap Intensitas Mual Muntah Pada Ibu Hamil Di Puskesmas Sei Semayang Tahun 2021}

Berdasarkan hasil penelitian diperoleh bahwa ibu hamil yang mengalami mual muntah sebelum diberikan intervensi mengalami mual muntah dalan kategori sedang dan setelah diberikan intervensi mengalami mual muntah dalam kategori ringan. Berdasarkan hasil pengukuran terjadi kecenderungan penurunan intensitas mual sesudah diberikan intervesi aroma terapi kulit jeruk dengan rata-rata penurunan 0,906 dan kecenderungan terjadi penurunan muntah sebelum dan sesudah intervensi dengan rata-rata 0,875 . Tingkat emesis gravidarum yang dialami oleh setiap ibu hamil berbeda-beda karena setiap wanita hamil memiliki keuninkan masing- masing. Menurut penelitian yang dilakukan oleh (Vitrianingsih, Khadihah S 2019) pengukuran score frekuensi mual muntah pada ibu hamil dari 20 responden setelah diberikan aromaterapi lemon rata-rata score mual muntah adalah 19,85.

Perlakuan yang diberikan yaitu ibu menghirup aromaterapi kulit jeruk yang dengan jarak kurang lebih $2 \mathrm{~cm}$ dari hidung sambil bernafas panjang selama kurang lebih 5 menit dan bisa diulang jika masih merasa mual. Aromaterapi kulit jeruk merupakan salah satu aromaterapi yang efektif dalam mengurangi mual dan muntah. Minyak essensial lemon berasal dari ekstraksi kulit jeruk jeruk (Citrus jeruk) merupakan salah satu jenis aromaterapi yang aman untuk kehamilan dan melahirkan (Medforth, 2013). Young (2011) menyampaikan bahwa minyak essensial lemon mengandung limonene $66-80 \%$, geranil asetat, nerol, linalil asetat, $\beta$ pinene $0,4-$ $15 \%$, a pinene $1-4 \%$, terpinene $6-14 \%$ dan myrcen. Senyawa kimia seperti geranil asetat, nerol, linalil asetat, memiliki efek antidepresi, antiseptik, antispasmodik, penambah gairah seksual dan obat penenang ringan (Namazi, et al, 2014).

Uji paired t-test didapatkan $p$-value $0,000<0,05$ artinya ada pengaruh pemberian aromaterapi kulit jeruk terhadap penurunana mual dan muntah pada ibu hamil. Setelah pemberian aromaterapi kulit jeruk sebagian besar responden mengatakan merasa lebih segar, tenang dan nyaman dimana sensasi mual tidak lagi terlalu kuat dirasakan seperti sebelum pemberian aromaterapi kulit jeruk. Setelah pemberian aromaterapi kulit jeruk responden juga menyatakan bahwa frekuensi mual muntah mulai berkurang, dimana ibu mengalami mual muntah terutama pada pagi hari tidak seperti biasanya dan pada waktu-waktu berikutnya yaitu siang dan malam hari frekuensi mual muntah yang dialami ibu sudah semakin sedikit, Kondisi ini mengindikasikan bahwa dengan pemberian inhalasi aromaterapi Kulit jeruk dapat menurunkan frekuensi mual dan muntah pada ibu hamil yang mengalami emesis gravidarum. Berbagai penelitian sejalan dengan hasil penelitian ini antara lian penelitian yang dilakukan oleh Rofi'ah (2019) bahwa terdapat perbedaan derajat emesis gravidarum pada ibu hamil antara sebelum dan setelah diberikan aromaterapi lemon, dimana tingkat emesis gravidarum sebelum diberikan aromaterapi lemon pada rentang skor $3-23$ dan tingkat emesis gravidarum sesudah diberikan aromaterapi lemon pada rentang skor $0-19$.

Aromaterapi memberikan ragam efek bagi penghirupnya, seperti ketenangan, kesegaran, bahkan bisa membantu ibu hamil mengatasi mual. Aromaterapi minyak esensial dapat mengatasi keluhan fisik dan psikis. Yang paling sederhana adalah melalui indra penciuman dengan mencium aroma dari minyak esensial. Pemakaian minyak essensial tumbuhan pada aromaterapi tidak dianggap benda asing di dalam tubuh, sehingga tidak memperberat kerja organ tubuh (Santi, 2013). Minyak atsiri 
dapat secara positif mempengaruhi suasana hati seseorang, pola tidur, tingkat energi, rasa percaya diri sehingga bisa mengurangi rasa mual dan muntah.

\section{SIMPULAN DAN SARAN}

\section{SIMPULAN}

Kesimpulan dari penelitian dengan Judul Pengaruh Aromaterapi Kulit Jeruk Terhadap Intensitas Mual Muntah pada Ibu Hamil di Puskesmas Sei Semayang maka disimpulkan ada ada Judul Pengaruh Aromaterapi Kulit Jeruk Terhadap Intensitas Mual Muntah pada Ibu Hamil di Puskesmas Sei Semayang Kecamatan Sunggal Kabupaten Deli Serdang Tahun 2021 dengan nilai $p=0,000$.

\section{SARAN}

Disarankan kepada responden dapat melalukan aroma terapi untuk mengurangi intensitas mual muntah tidak karena efek non farmakologis ini sangat bermanfaat sehingga responden dapat manjalani kehamilan dengan baik. Disarankan kepada Puskesmas Sei Semayang Kecamatan Sunggal Kabupaten Deli Serdang dapat melakukan intervesi pemberian tindakan non farmakologis dengan aroma terapi kulit jeruk pada ibu hamil untuk mengutangi mual muntah sehingga responden tetap merasa nyaman dalam kehamilannya.

\section{DAFTAR PUSTAKA}

Arikunto, S. 2010. Prosedur Penelitian Suatu Pendekatan Praktik. Jakarta: PT Rineka Cipta

Astuti, Sri. dkk. (2017). Asuhan Ibu dalam Masa Kehamilan. Jakarta: Erlangga

BNPB-inacovid19, 2012. Jumlah Kasus Terkonfirmasi Covid 19, https://bnpbinacovid19.hub.arcgis.com/ diakses tanggal 1 April 2021

Cunningham FG, Leveno KJ, Bloom SL, Hauth JC, et al. Perawatan Pranatal. In: Obstetri Williams. Edisi 23. Jakarta: ECG; 2012

Doenges, M. E., Moorhouse, M. F., \& Geissler, A. C, 2014. Rencana Asuhan Keperawatan Pedoman Untuk Perencanaan dan Pendokumentasian Perawatan Pasien. Jakarta: EGC.

Ibanez, G., dkk. (2015). Effects of Atenatal Maternal Depression and Anxiety on Children's Early Cognitive Development: A Prospective Cohort Study. PLoS One, Vol. 10, No 8, August 2015, DOl:10.1371/journal.pone.0135849.

Kementerian Kesehatan RI Direktorat Jenderal Kesehatan Masyarakat 2020, Pedoman Pelayanan Antenatal, Persalinan, Nifas, Dan Bayi Baru Lahir Di Era Adaptasi Kebiasaan Baru, Jakarta : Kementerian Kesehatan RI. 
Kementerian Kesehatan RI 2014, Buku Ajar Kesehatan Ibu dan Anak, Pusat Pendidikan dan Pelatihan Tenaga Kesehatan, Jakarta : Kementerian Kesehatan RI.

Kementerian Kesehatan RI, 2015, Pedoman Pelayanan Antenatal Terpadu Edisi Kedua, Jakarta

Maternity, D Putri A, Dewi Y. 2017. Inhalasi Lemon Mengurangi Mual Muntah Pada Ibu Hamil Trimester Satu. Jurnal IImiah Bidan. Vol 2 (3)

Namazi, M., Akbari, A.S., Mojab, F.,Talebi, A., Majd, H.A. \& Jannesari,S. (2014) Aromatherapy With Citrus aurantium Oil and Anxiety during the First Stage of Labor. Iranian Journal Of Pharmaceutical Research

Notoatmodjo, S. 2015. Metodologi Penelitian Kesehatan. PT Rineka Cipta. Jakarta.

Nursalam. 2015. Konsep dan Penerapan Metodologi Penelitian Ilmu Keperawatan, Pedoman Skripi, Tesis dan Instrumen Penelitian Keperawatan. Sagung Seto. Jakarta.

Rofi'ah, S. (2019). Studi Fenomologi Kejadian Hiperemesis Gravidarum pada Ibu Hamil Tromester I. Jurnal Riset Kesehatan, Vol 8 (1): $42-52$

Saifuddin, A.B. 2015, Buku Acuan Nasional Pelayanan Kesehatan Maternal dan Neonatal. Jakarta: Yayasan Bina Pustaka Sarwono Prawirohardjo.

Saragih AW, 2016. Efektifitas Aroma Terapi Lemon dalam Mengurangi Mual Muntah pada IbuHamil Trisemester Pertama, Universitas sumatera Utara.

Santi, D. R. (2013). Pengaruh Aromaterapi Blended Peppermint dan Ginger Oil terhadap Rasa Mual pada lbu Hamil Trimester Satu di Puskesmas Rengel Kabupaten Tuban (The Effect of Peppermint and Ginger Blended Aromatherapy Oils on Nausea at the First Trimester Gravida in Puskesmas. Sain Med, Vol 5(2): 52-55

Shodiqoh, E.R., \& Syahrul, F. (2014). Perbedaan Tingkat Kecemasan dalam Menghadapi Persalinan antara Primigravida dan Multigravida. Jurnal Berkala Epidemiologi. 2(1), 141-150. Diterima dari http://www.jounal.unair.ac.id/download-full/JBE8534-d73df33709fullabstr act.pdf, diakses pada tanggal 30 Maret 2021

Sugiyono. 2014. Statistik. PT. Gramedia Pustaka Utama. Jakarta.

UK Obstretic Surveillance System, 2020. A National System to Study Rare Disorders of Pregnancy, https://www.npeu.ox.ac.uk/ukoss, diakses tanggal 30 Maret 2021

Vitrianingsih, Khadijah (2019). Efektivitas Aroma Terapi Lemon Untuk Menangani Emesis Gravidarum, Jurnal Keperawatan Volume 11 No 4. Yogyakarta. 
WHO. (2013). Interventions for Common Perinatal Mental Disorder In Women In Low- and Middle-Income Countries: A Systematic Review and Metaanalysis

Xu H, Zhong L, Deng J, Peng J, Dan H, Zeng X, et al. 2020. High expression of ACE2 receptor of $2019-n C o V$ on the epithelial cells of oral mucosa. International Journal of Oral Science. 12 (1): 8. doi:10.1038/s41368-020- 0074$\mathrm{x})$ 